\title{
Keanekaragaman Jenis Katak dan Kodok (Amphibia: Anura) di Sungai Gadjah Wong, Daerah Istimewa Yogyakarta
}

\section{Diversity of Frogs and Toads (Amphibia: Anura) at Gadjah Wong River, Province of DIY}

Donan Satria Yudha ${ }^{1 *}$, Rury Eprilurahman', Ayu Maulida Sukma², Sekar Arum Setyaningrum ${ }^{2}$

1) Laboratorium Sistematika Hewan, Fakultas Biologi Universitas Gadjah Mada

2) Kelompok Studi Herpetologi, Fakultas Biologi Universitas Gadjah Mada

E-mail: donan_satria@ugm.ac.id*Penulis untuk korespondensi

\begin{abstract}
Research concerning on the diversity of frogs and toads of Code River has been done and published by Yudha, et al, (2013) and also those of Opak River (Yudha, et al, 2014). Gadjah Wong River is one of the big and important rivers in Province of DIY. Research concerning the diversity of frogs and toads of Gadjah Wong River probably has not been done due to lack of publication about it. The research was aimed to acquire data about the diversity of frogs and toads which inhabit along Gadjah Wong River. Samples taken using three combination methods: VES (Visual Encounter Survey), River bank cruising and transect. Sampling area were generally divided into three locations i.e., upstream, middle-stream and downstream. The results showed 6 species of frogs and toads, they were Chalcorana chalconota, Occidozyga sumatrana, Fejervarya limnocharis, Polypedates leucomystax, Duttaphrynus melanostictus, and Ingerophrynus biporcatus. All frogs and toads found were common anurans. From six species of frogs and toads, one could recognize several specific habitats, i.e. 3 aquatic and semi-aquatic species, 1 arboreal species and 2 terrestrial species. Gadjah Wong River is a quite decent habitat for some species of frogs and toads.
\end{abstract}

Key words: diversity, frogs, toads, Gadjah Wong River, Yogyakarta

Abstrak

Penelitian mengenai keanekaragaman katak dan kodok di sepanjang daerah sungai di Yogyakarta telah dilaksanakan oleh Yudha, dkk (2013) di Sungai Code dan Yudha, dkk (2014) di Sungai Opak oleh. Sungai Gadjah Wong merupakan salah satu sungai besar dan penting di Propinsi Daerah Istimewa Yogyakarta. Penelitian mengenai keanekaragaman katak dan kodok di Sungai Gadjah Wong belum banyak dipublikasikan. Penelitian ini bertujuan mengetahui keanekaragaman jenis katak dan kodok (Amphibia: Anura) yang menempati Sungai Gadjah Wong sebagai habitatnya. Pengambilan sampel di sepanjang Sungai Gadjah Wong dari hulu hingga hilir menggunakan metode: VES (Visual Encounter Survey), river bank cruising, dan transek. Sampling secara umum dibagi menjadi tiga bagian, bagian hulu, tengah dan hilir. Hasil yang diperoleh yaitu 6 jenis katak dan kodok (Amphibia: Anura), terdiri dari Chalcorana chalconota, Occidozyga sumatrana, Fejervarya limnocharis, Polypedates leucomystax, Duttaphrynus melanostictus, dan Ingerophrynus biporcatus. Semua katak dan kodok yang dijumpai tersebut adalah jenis yang umum dijumpai. Dari keenam katak tersebut dapat diketahui habitatnya yaitu: 3 jenis katak akuatik dan semi-akuatik, dan 1 jenis katak arboreal serta 2 jenis katak terrestrial. Berdasarkan hasil tersebut dapat diketahui bahwa Sungai Gadjah Wong merupakan habitat yang cukup sesuai bagi sebagian jenis katak dan kodok.

Kata kunci: keanekaragaman, katak, kodok, Sungai Gadjah Wong, Yogyakarta

Diterima: 3 Februari 2017, disetujui: 26 Maret 2017

\section{Pendahuluan}

Katak dan kodok merupakan nama umum dari kelompok hewan amifibi, yang secara taksonomi masuk ke dalam kelas Amphibia dan ordo Anura (Zug dkk., 2001; Vitt \& Caldwell, 2014). Penelitian mengenai keanekaragaman katak dan kodok di sungai-sungai di Daerah 
Istimewa Yogyakarta (DIY) telah dilakukan dan dipublikasikan. Keanekaragaman katak dan kodok di Sungai Code telah dilakukan dan dipublikasikan oleh Yudha dkk., (2013) dan penelitian katak dan kodok di Sungai Opak oleh Yudha, dkk., (2014). Pada penelitian Sungai Code (2013), keanekaragaman terendah terdapat di bagian tengah sungai, yaitu bagian sungai yang berada di dalam Ring Road Yogyakarta dan melewati Kota Yogyakarta, yaitu area padat penduduk. Sedangkan penelitian di Sungai Opak (2014), keanekaragaman terendah berada di bagian hilir sungai. Bagian tengah Sungai Opak tidak berada di dalam Ring Road Yogyakarta, tetapi berada di sebelah selatan Candi Prambanan. Bagian tengah Sungai Opak banyak vegetasi riparian, tepian sungai berbatu, dengan genangan air yang dangkal dan sedikit bangunan perumahan maupun aktivitas manusia di sekitar sungai.

Sungai Gadjah Wong adalah salah satu sungai besar dan penting yang mengalir di wilayah DIY. Penelitian mengenai keanekaragaman katak dan kodok di Sungai Gadjah Wong mungkin belum pernah ada atau belum pernah dipublikasikan. Bagian Hulu sungai Gadjah Wong berada di lereng selatan Gunung Merapi, wilayah Kabupaten Sleman. Bagian Tengah Sungai Gadjah Wong mengalir di dalam Ring Road dan melewati Kota Yogyakarta yang merupakan wilayah padat penduduk. Bagian Hilir Sungai Gadjah Wong menyatu dengan Sungai Opak di Kabupaten Bantul. Katak dan kodok memerlukan air dalam siklus kehidupannya (Zug dkk., 2001; Vitt \& Caldwell, 2014). Kondisi badan air di sungaisungai di DIY banyak mengalami perubahan dan hal tersebut dapat mempengaruhi keberadaan jenis-jenis anura yang habitatnya di sekitar sungai, terutama Sungai Gadjah Wong (Siradz, dkk., 2008).

Keanekaragaman jenis katak dan kodok pada habitat di sekitar sungai-sungai di Propinsi DIY dirasa masih kurang lengkap, terutama dari sisi jumlah sungai. Diperlukan pendataan wilayah sungai di DIY yang lebih lengkap. Penelitian ini bertujuan untuk mengetahui keanekaragaman jenis katak dan kodok yang terdapat di sepanjang Sungai Gadjah Wong, Propinsi Daerah Istimewa Yogyakarta. Keanekaragaman tersebut berguna untuk memberikan informasi lebih lengkap dan database yang dapat dijadikan acuan bagi penelitian selanjutnya.

\section{Metode Penelitian}

Spesimen yang dipelajari adalah semua jenis katak dan kodok yang dijumpai di dalam maupun tepian kanan-kiri sepanjang Sungai Gadjah Wong dari hulu hingga hilir di Propinsi D.I.Y. Bahan kimia (etanol 70\%, formaldehid $4 \%$, akuades dan kloroform) digunakan untuk pembuatan awetan basah sebagai spesimen.

Penelitian dilakukan selama bulan Juni hingga Agustus 2014. Lokasi penelitian terletak di sepanjang Sungai Gadjah Wong dari hulu hingga hilir. Metode yang digunakan adalah transek garis virtual sepanjang $500 \mathrm{~m}$ per titik sampling dengan kombinasi visual encounter survey (VES) (Crump \& Scott, 1994; Jaeger, 1994; Guyer \& Donnelly, 2012). Pada bagian hulu, tengah dan hilir Sungai Gadjah Wong masing-masing ditentukan 3 titik sampling (Tabel 1). Pengambilan data pada setiap titik sampling dilakukan dalam dua kali yaitu siang hari untuk menemukan anura diurnal dan malam hari untuk mendapatkan anura nokturnal. Kemudian satu individu pada masing-masing jenis diambil dan diawetkan sebagai specimen voucher (Reynolds dkk., 1994; Reynolds \& McDiarmid, 2012).

Semua spesimen katak dan kodok yang dijumpai ditangkap dengan tangan, diidentifikasi dan didokumentasi. Sampling katak dan kodok dilakukan pada sepanjang tepian sungai. Satu individu dewasa tiap jenis diambil sebagai voucher specimen. Spesimen dibuat sebagai awetan basah yang diawetkan dengan etanol $70 \%$ dan diberi label. Identifikasi dilaksanakan berdasarkan panduan menurut Iskandar (1998), Kurniati (2003) dan Kusrini (2009).

\section{Hasil dan Pembahasan}

Katak dan kodok yang dijumpai pada Sungai Gadjah Wong dari hulu hingga hilir total berjumlah enam spesies yang tergolong ke dalam empat familia, yaitu: Chalcorana chalconota (Kongkang kolam) dari familia Ranidae, Fejervarya limnocharis (Katak tegalan) dan 
Occidozyga sumatrana (Bancet rawa Sumatera) dari familia Dicroglossidae, Polypedates leucomystax (Katak pohon bergaris) dari familia Rhacophoridae, Duttaphrynus melanostictus (Kodok buduk, kodok puru) dan Ingerophrynus biporcatus (Kodok puru hutan) dari familia Bufonidae. Katak Chalcorana chalconota memiliki jumlah individu terbanyak dengan 20 individu, diikuti dengan Polypedates leucomystax dengan 19 individu dan Duttaphrynus melanostictus dengan 16 individu (Tabel 2).

Sampling katak dan kodok di bagian Hulu Gadjah Wong baik saat siang maupun malam dari tiga titik sampling didapatkan enam jenis katak dan kodok (Tabel 3). Enam jenis katak dan kodok yang dijumpai yaitu: Chalcorana chalconota, Fejervarya limnocharis, Occidozyga sumatrana, Polypedates leucomystax, Duttaphrynus melanostictus, dan Ingerophrynus biporcatus. Katak dan kodok yang paling banyak dijumpai di bagian hulu adalah Polypedates leucomystax dengan 14 individu dan Chalcorana chalconota dengan sembilan individu (Tabel 2). Katak Polypedates leucomystax banyak dijumpai di habitat dengan banyak vegetasi riparian yang lembab di sekitar rawa atau sungai, kemudian Chalcorana chalconota banyak dijumpai di habitat tepian sungai berbatu dengan arus air tenang atau menggenang. Berdasarkan preferensi habitat kedua jenis anura yang cukup banyak tersebut, dapat dikatakan bahwa secara umum bagian hulu Sungai Gadjah Wong masih relatif banyak vegetasi riparian dengan badan air yang jernih dan cukup melimpah (Gambar 1).

Katak dan kodok yang dijumpai di bagian hulu sebagian besar dijumpai pada saat sampling malam hari. Hal tersebut dikarenakan sebagian besar jenis katak dan kodok beraktivitas di malam hari, terutama berkaitan dengan banyaknya jenis serangga sebagai makanan katak dan kodok yang muncul di malam hari.

Pada Titik Sampling 1 paling sedikit dijumpai anura yaitu dengan tiga jenis, karena bagian hulu digunakan sebagai tambang pasir, sehingga banyak aktivitas manusia di area tersebut. Pada Titik Sampling 2 adalah area yang sepi kegiatan manusia, karena lokasinya di tebing yang agak tinggi, dengan vegetasi riparian rimbun dan lebar sungai yang sempit berbatu, sehingga dijumpai empat jenis karena lokasinya sesuai sebagai habitat anura. Pada Titik Sampling 3 dijumpai empat jenis anura, area tersebut cocok bagi keberadaan anura karena: sepi dari kegiatan manusia, tepiannya rimbun dengan vegetasi riparian, berbatu serta jauh dari hunian manusia. Selain itu, badan air di bagian TS 3 menggenang sehingga merupakan habitat yang sesuai bagi anura (Gambar 1).

Tabel 1. Lokasi area kajian di Sungai Gadjah Wong dari Hulu hingga Hilir.

\begin{tabular}{lll}
\hline Sungai Gadjahwong & Titik Sampling (TS) & \multicolumn{1}{c}{ Nama Lokasi } \\
\cline { 2 - 3 } Hulu & TS I & $\begin{array}{l}\text { Dusun Turen, Desa Sardonoharjo, Kecamatan Ngaglik, } \\
\text { Kabupaten Sleman }\end{array}$ \\
\cline { 2 - 3 } TS II & $\begin{array}{l}\text { Dusun Plosokuning 2, Desa Minomartani, Kecamatan Ngaglik, } \\
\text { Kabupaten Sleman }\end{array}$ \\
\cline { 2 - 3 } TS III & $\begin{array}{l}\text { Dusun Krangkungan, Desa Condong Catur, Kecamatan Depok, } \\
\text { Kabupaten Sleman }\end{array}$ \\
\hline TS I & $\begin{array}{l}\text { Dusun Dabag, Desa Condong Catur, Kecamatan Depok, } \\
\text { Kabupaten Sleman }\end{array}$ \\
\cline { 2 - 3 } Tengah & TS II & $\begin{array}{l}\text { Dusun Plumbon, Desa Banguntapan, Kecamatan Banguntapan, } \\
\text { Kabupaten Bantul }\end{array}$ \\
\cline { 2 - 3 } Hilir & TS III & $\begin{array}{l}\text { Dusun Dladan, Desa Wirokerten, Kecamatan Banguntapan, } \\
\text { Kabupaten Bantul }\end{array}$ \\
\hline TS I & $\begin{array}{l}\text { Dusun Mintoragan, Desa Wirokerten, Kecamatan Banguntapan, } \\
\text { Kabupaten Bantul }\end{array}$ \\
\cline { 2 - 3 } TS II & $\begin{array}{l}\text { Dusun Kanggotan, Desa Pleret, Kecamatan Pleret, Kabupaten } \\
\text { Bantul }\end{array}$ \\
\cline { 2 - 3 } & TS III & Dusun Karet, Desa Pleret, Kecamatan Pleret, Kabupaten Bantul \\
\hline
\end{tabular}


Keanekaragaman Jenis Katak dan Kodok

Tabel 2. Total individu setiap jenis katak dan kodok yang dijumpai di Sungai Gadjah Wong

\begin{tabular}{cllcccc}
\hline No. & \multicolumn{1}{c}{ Familia } & \multicolumn{1}{c}{ Spesies } & Hulu & Tengah & Hilir & Total individu \\
\hline 1. & Ranidae & Chalcorana chalconota & 9 & 5 & 6 & 20 \\
2. & Dicroglossidae & Fejervarya limnocharis & 2 & 0 & 1 & 3 \\
3. & & Occidozyga sumatrana & 2 & 0 & 0 & 2 \\
4. & Rhacophoridae & Polypedates leucomystax & 14 & 0 & 5 & 19 \\
5. & Bufonidae & Duttaphrynus melanostictus & 1 & 7 & 8 & 16 \\
6. & & Ingerophrynus biporcatus & 4 & 1 & 0 & 5 \\
\hline
\end{tabular}

Tabel 3. Katak dan kodok yang dijumpai di bagian Hulu Sungai Gadjah Wong tahun 2014.

\begin{tabular}{lllccc}
\hline \multirow{2}{*}{ No. } & \multirow{2}{*}{ Familia } & \multicolumn{1}{c}{ Spesies } & \multicolumn{3}{c}{ Hulu Gadjah Wong } \\
\cline { 3 - 6 } & & Chalcorana chalconota & TS 1 & TS 2 & TS 3 \\
\hline 1. & Ranidae & Occidozyga sumatrana & - & $\mathrm{M}$ & $\mathrm{M}$ \\
2. & Dicroglossidae & Fejervarya limnocharis & - & $\mathrm{M}$ & - \\
3. & & P/M & $\mathrm{M}$ & $\mathrm{P} / \mathrm{M}$ \\
4. & Rhacophoridae & Polypedates leucomystax & - & - & $\mathrm{M}$ \\
5. & Bufonidae & Duttaphrynus melanostictus & P/M & - & - \\
6. & & Ingerophrynus biporcatus & 3 spesies & $\mathbf{4}$ spesies & $\mathbf{4}$ spesies \\
\hline
\end{tabular}

Keterangan: $\mathbf{T S}=$ Titik Sampling; $\mathbf{P}=$ sampling pagi; $M=$ sampling malam

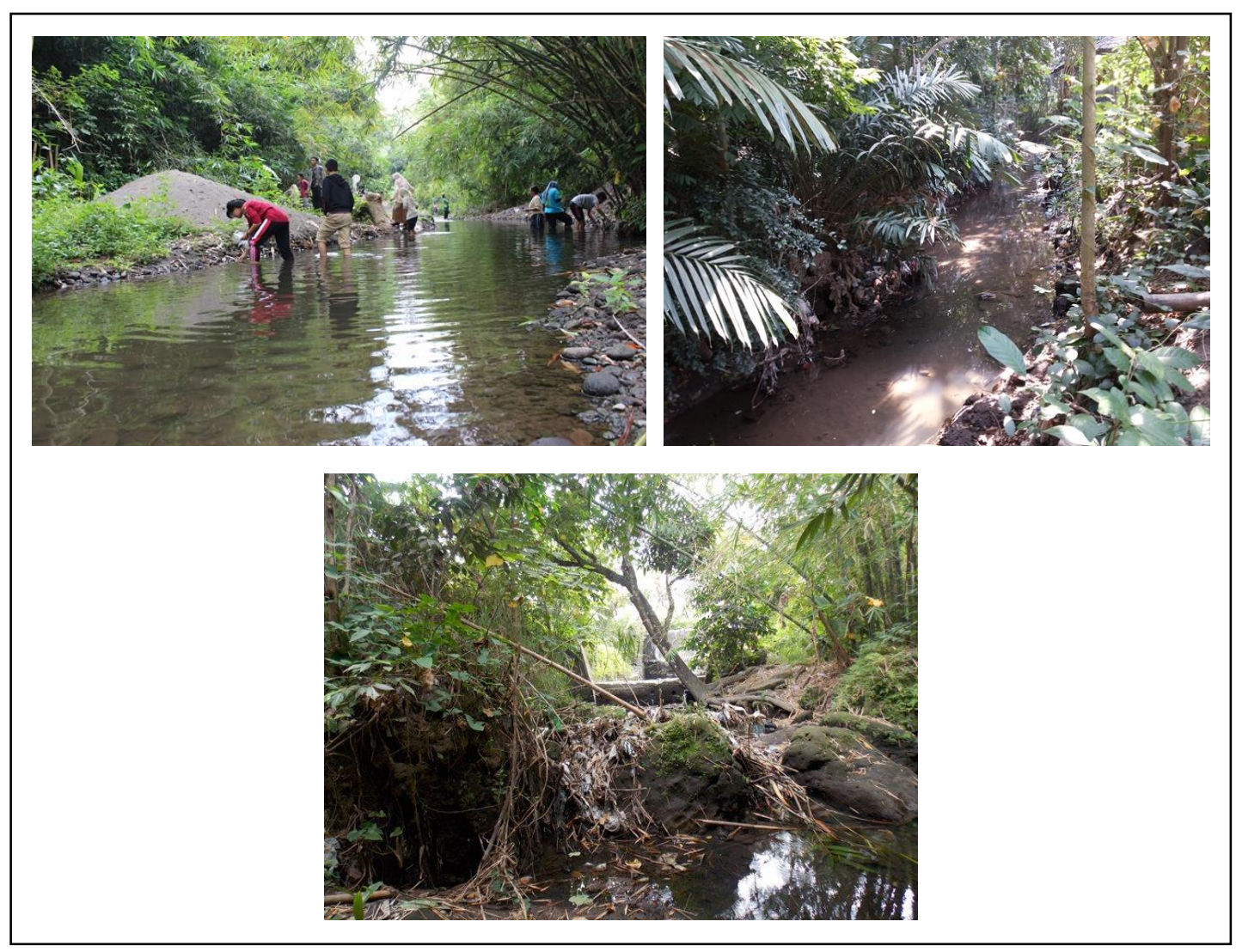

Gambar 1. Bagian Hulu Sungai Gadjah Wong, Kiri: Titik Sampling 1, tampak bukit pasir di tepian sungai, hasil penambangan pasir oleh warga; Kanan: Titik Sampling 2 tampak vegetasi riparian yang rimbun dan berbatu; Bawah: Titik Sampling 3 tampak rimbun, berbatu dan air sungai menggenang. 
Katak Chalcorana chalconota dan Polypedates leucomystax dijumpai pada tiga Titik Sampling di bagian hulu (Gambar 2), keduanya juga memiliki jumlah individu terbanyak di bagian hulu, hal tersebut menandakan bahwa kondisi hulu Sungai Gadjah Wong banyak digenangi air dan dengan bebatuan ditepian sungai serta vegetasi riparian yang cukup lebat. Keberadaan empat individu Ingerophrynus biporcatus pada bagian hulu menandakan bahwa di hulu merupakan area dengan tumbuhan yang lebat mirip seperti hutan sekunder maupun perkebunan dengan air sungai yang menggenang. Dua individu Occidozyga sumatrana menandakan area sungai berupa genangan air, berhutan atau area dengan tumbuhan lebat, hal tersebut mirip dengan preferensi habitat dari Ingerophrynus biporcatus. Sedangkan dua individu Fejervarya limnocharis menandakan adanya area persawahan dan padang rumput dekat dengan hulu Sungai Gadjah Wong.

Sampling katak dan kodok dibagian Tengah Gadjah Wong baik saat siang maupun malam dari tiga titik sampling didapatkan lima jenis katak dan kodok (Tabel 4). Lima jenis katak dan kodok yang dijumpai yaitu: Chalcorana chalconota, Fejervarya limnocharis, Polypedates leucomystax, Duttaphrynus melanostictus dan Ingerophrynus biporcatus. Katak dan kodok yang paling banyak dijumpai dibagian tengah Sungai Gadjah Wong adalah Duttaphrynus melanostictus (kodok buduk) dengan tujuh individu dan Chalcorana chalconota dengan lima individu (Tabel 2).

Duttaphrynus melanostictus memiliki ciri banyak dijumpai pada habitat terganggu. Habitat terganggu adalah habitat alami yang telah banyak aktivitas manusia bahkan telah diubah menjadi hunian manusia. Chalcorana chalconota menyukai habitat tepian sungai berbatu dengan arus air tenang dan menggenang. Berdasarkan preferensi habitat kedua jenis anura yang cukup banyak tersebut, dapat dikatakan bahwa bagian tengah Sungai Gadjah Wong banyak dijumpai aktivitas manusia bahkan hunian manusia yang dekat dengan badan air, dan badan air yang ada cukup melimpah (Gambar 3). Keberadaan satu individu jenis Ingerophrynus biporcatus (kodok puru hutan) pada bagian tengah tidak bisa menandakan bahwa di tengah merupakan area dengan tumbuhan yang lebat mirip seperti hutan sekunder maupun perkebunan dengan air sungai yang menggenang, karena hanya dijumpai satu individu dan jenis ini kadang juga dijumpai dekat hunian manusia.

Pada Titik Sampling 1 paling banyak dijumpai anura yaitu dengan empat jenis, karena lokasi Titik Sampling 1 Tengah merupakan area dengan vegetasi riparian yang cukup lebat, pada satu sisi tepi sungai landai dan jauh dari hunian manusia, dan pada sisi lainnya dengan talud (tembok pembatas tepian sungai) tinggi. Pada Titik Sampling 2 paling sedikit dijumpai anura yaitu dua jenis, karena lokasi Titik Sampling tersebut dekat dengan hunian manusia, yaitu adanya pengempul barang bekas dan rongsokan pada satu sisi sungai. Sedangkan lokasi Titik Sampling 3 dijumpai tiga jenis anura, cukup banyak spesies anura dijumpai karena kondisi sungai yang sepi aktivitas manusia baik siang maupun malam, serta banyak vegetasi riparian di satu sisi serta rerumputan luas di sisi lainnya (Gambar 3).

Tabel 4. Katak dan kodok yang dijumpai di bagian Tengah Sungai Gadjah Wong tahun 2014.

\begin{tabular}{cllccc}
\hline \multirow{2}{*}{ No. } & \multirow{2}{*}{ Familia } & & \multicolumn{1}{c}{ Spesies } & \multicolumn{2}{c}{ Tengah Gadjah Wong } \\
\cline { 3 - 6 } & & Chalcorana chalconota & $\mathrm{M}$ & $\mathrm{TS}$ 2 & TS 3 \\
\hline 1. & Ranidae & Fejervarya limnocharis & $\mathrm{M}$ & - & $\mathrm{M}$ \\
2. & Dicroglossidae & Polypedates leucomystax & - & - & $\mathrm{M}$ \\
3. & Rhacophoridae & Duttaphrynus melanostictus & $\mathrm{P} / \mathrm{M}$ & $\mathrm{P} / \mathrm{M}$ & $\mathrm{P} / \mathrm{M}$ \\
4. & Bufonidae & Ingerophrynus biporcatus & $\mathrm{P}$ & - & - \\
5. & & & 4 spesies & 2 spesies & 3 spesies \\
\hline
\end{tabular}

Keterangan: $\mathbf{P}$ = sampling pagi; $\mathrm{M}=$ sampling malam 


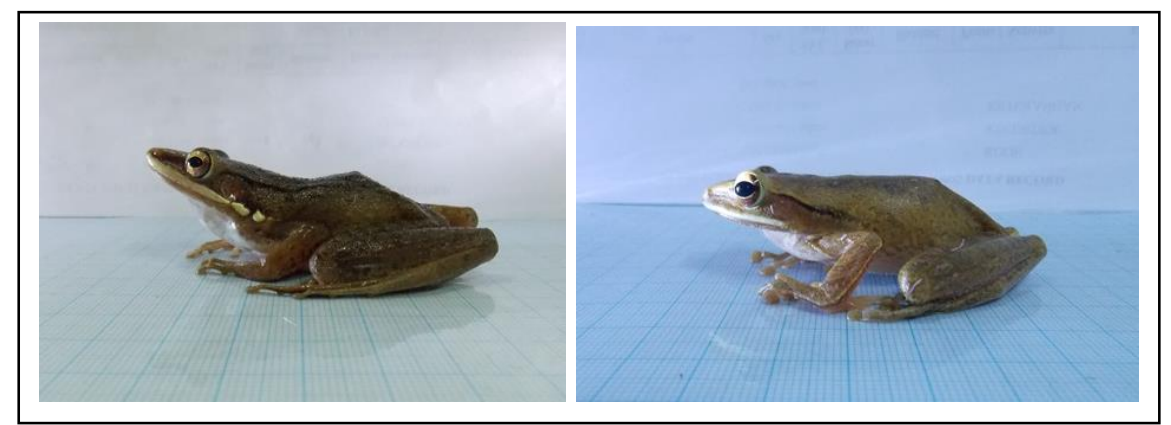

Gambar 2. Katak yang dijumpai di Hulu Sungai Gadjah Wong, kiri: Chalcorana chalconota (Kongkang kolam), dan kanan: Polypedates leucomystax (Katak-pohon bergaris).

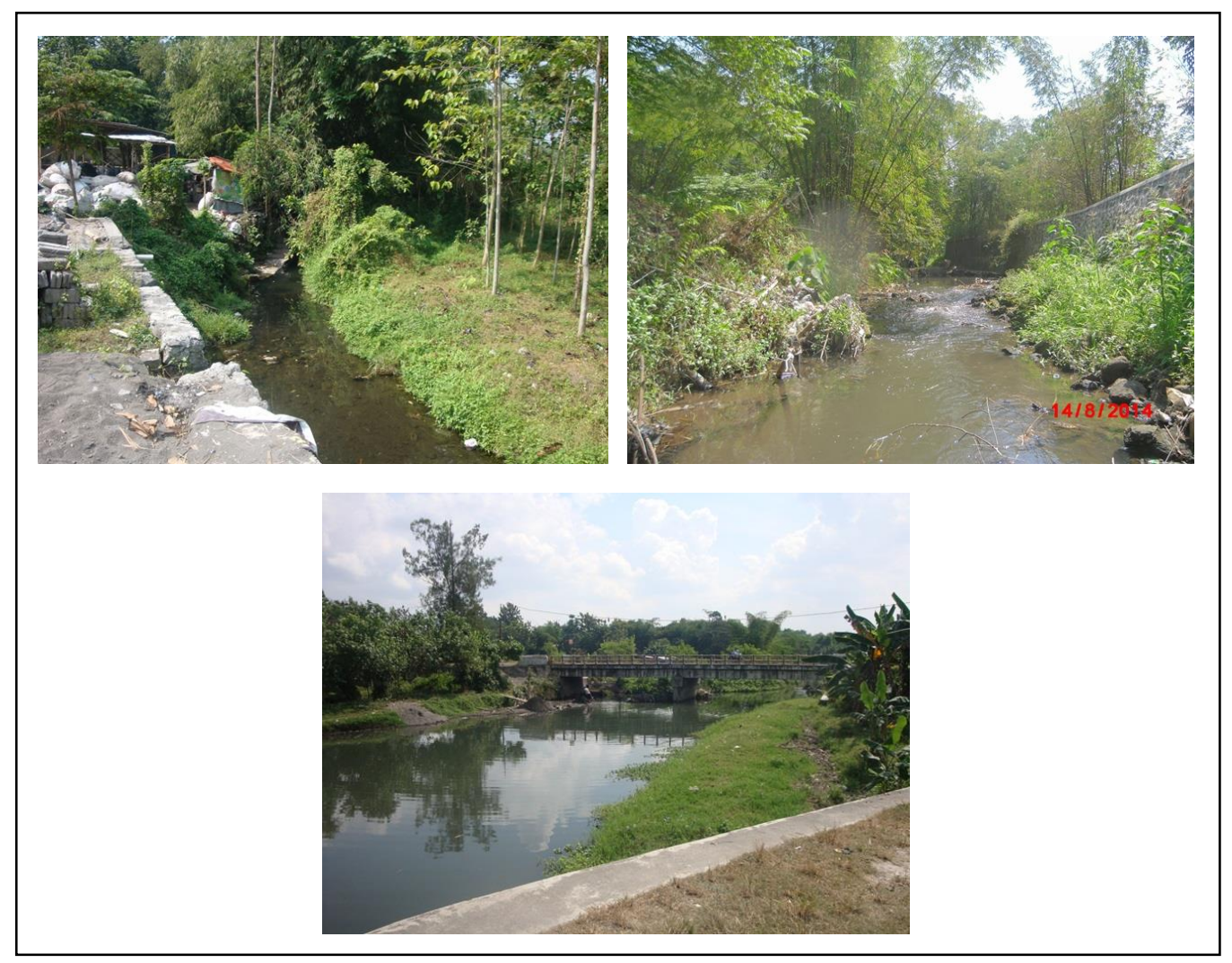

Gambar 3. Bagian Tengah Sungai Gadjah Wong, Kiri: Titik Sampling 1, tampak hunian warga ditepi sungai; Kanan: Titik Sampling 2 tampak vegetasi riparian yang rimbun dan berbatu; Bawah: Titik Sampling 3 tampak tepian sungai yang luas, rimbun dan jauh dari hunian warga. 
Dua spesies kodok, dari familia Bufonidae, yaitu Duttaphrynus melanostictus dan Ingerophrynus biporcatus dijumpai pada bagian tengah Sungai Gadjah Wong (Gambar 4). Banyaknya individu Duttaphrynus melanostictus dan Ingerophrynus biporcatus yang dijumpai di hulu dengan tengah berbanding terbalik. Duttaphrynus melanostictus hanya dijumpai satu individu dibagian hulu dengan Ingerophrynus biporcatus dijumpai 4 individu. Pada bagian tengah, Duttaphrynus melanostictus dijumpai tujuh individu dan Ingerophrynus biporcatus hanya dijumpai satu individu (Tabel 2). Hal tersebut menandakan adanya perubahan tipe habitat karena perbedaan jumlah individu kodok yang ditemukan.

Sampling katak dan kodok dibagian Hilir Gadjah Wong baik saat siang maupun malam dari 3 titik sampling didapatkan empat jenis katak dan kodok (Tabel 5). Empat jenis katak dan kodok yang dijumpai yaitu: Chalcorana chalconota, Fejervarya limnocharis, Polypedates leucomystax, dan Duttaphrynus melanostictus. Jenis Chalcorana chalconota dan Fejervarya limnocharis sebagai penanda kondisi perairan yang jernih, tidak terlalu dalam dan alirannya tenang. Sedangkan jenis Polypedates leucomystax sebagai penanda adanya vegetasi riparian yang rindang. Kodok jenis Duttaphrynus melanostictus menandakan adanya aktivitas atau limbah buangan manusia di area tersebut.

Pada Titik Sampling 1 paling banyak dijumpai anura yaitu empat jenis, karena lokasi Titik Sampling 1 Hilir merupakan area dengan vegetasi riparian yang lebat, badan air yang menggenang dan jauh dari aktivitas manusia. Pada Titik Sampling 2 dijumpai tiga jenis anura, karena areanya cukup luas dengan delta sungai di satu sisi dan separuh vegetasi riparian di sisi satunya dengan badan air yang sempit tetapi mengalir lancar. Sedangkan Titik Sampling 3 dijumpai tiga jenis anura dengan keanekaragaman yang sama dengan Titik Sampling 2 karena kondisi tepian dan badan air tidak jauh berbeda dengan Titik Sampling 2 dan juga tidak ada aktivitas manusia baik siang maupun malam hari (Gambar 5).

Pada bagian hilir terdapat tiga jenis anura yang dijumpai pada ketiga titik sampling, yaitu: Chalcorana chalconota, Polypedates leucomystax dan Duttaphrynus melanostictus. Anura yang paling banyak dijumpai di bagian hilir Sungai Gadjah Wong adalah Duttaphrynus melanostictus dengan delapan individu dan Chalcorana chalconota dengan enam individu (Tabel 2). Hasil tersebut mirip dengan hasil pada bagian tengah sungai, sehingga dapat dikatakan bahwa bagian tengah Sungai Gadjah Wong banyak aktivitas manusia bahkan hunian manusia yang dekat dengan badan air, dan badan air yang ada cukup melimpah. Keberadaan lima individu Polypedates leucomystax menandakan bahwa kondisi vegetasi riparian yang rindang. Katak jenis Fejervarya limnocharis menandakan bahwa terdapat area persawahan dengan air menggenang yang tidak terlalu dalam (Gambar $6)$.

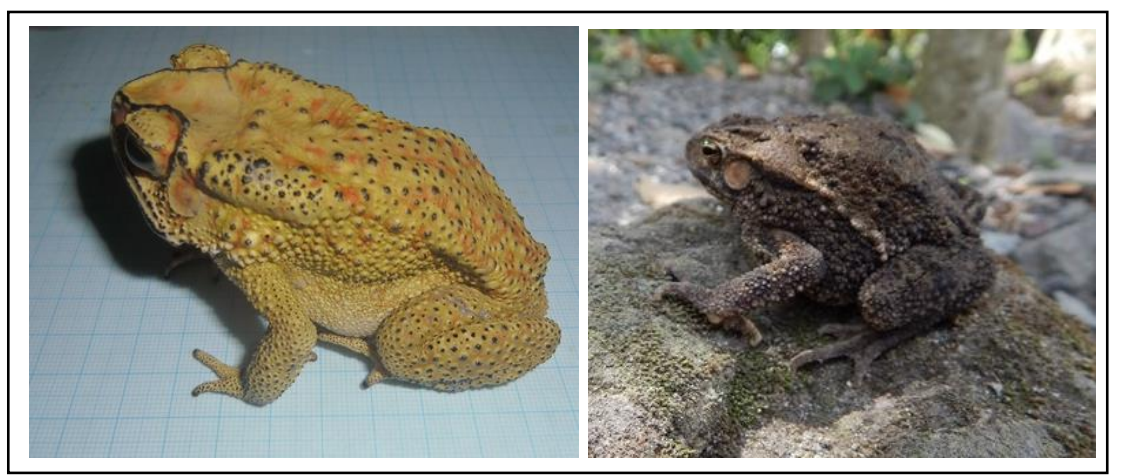

Gambar 4. Kodok yang dijumpai di Tengah Sungai Gadjah Wong, kiri: Duttaphrynus melanostictus (Kodok buduk, kodok puru), dan kanan: Ingerophrynus biporcatus (Kodok puru hutan). 
Keanekaragaman Jenis Katak dan Kodok

Tabel 5. Katak dan kodok yang dijumpai di bagian Hilir Sungai Gadjah Wong tahun 2014.

\begin{tabular}{|c|c|c|c|c|c|}
\hline \multirow{2}{*}{ No. } & \multirow{2}{*}{ Familia } & \multirow{2}{*}{ Spesies } & \multicolumn{3}{|c|}{ Hilir Gadjah Wong } \\
\hline & & & TS 1 & TS 2 & TS 3 \\
\hline 1. & Ranidae & Chalcorana chalconota & $\mathrm{M}$ & M & $\mathrm{M}$ \\
\hline 2. & Dicroglossidae & Fejervarya limnocharis & $\mathrm{P}$ & - & - \\
\hline 3. & Rhacophoridae & Polypedates leucomystax & $\mathrm{P} / \mathrm{M}$ & M & M \\
\hline \multirow[t]{2}{*}{4.} & Bufonidae & Duttaphrynus melanostictus & $\mathrm{M}$ & $\mathrm{P} / \mathrm{M}$ & M \\
\hline & & & 4 spesies & 3 spesies & 3 spesies \\
\hline
\end{tabular}

Keterangan: $\mathbf{P}=$ sampling pagi; $\mathbf{M}=$ sampling malam

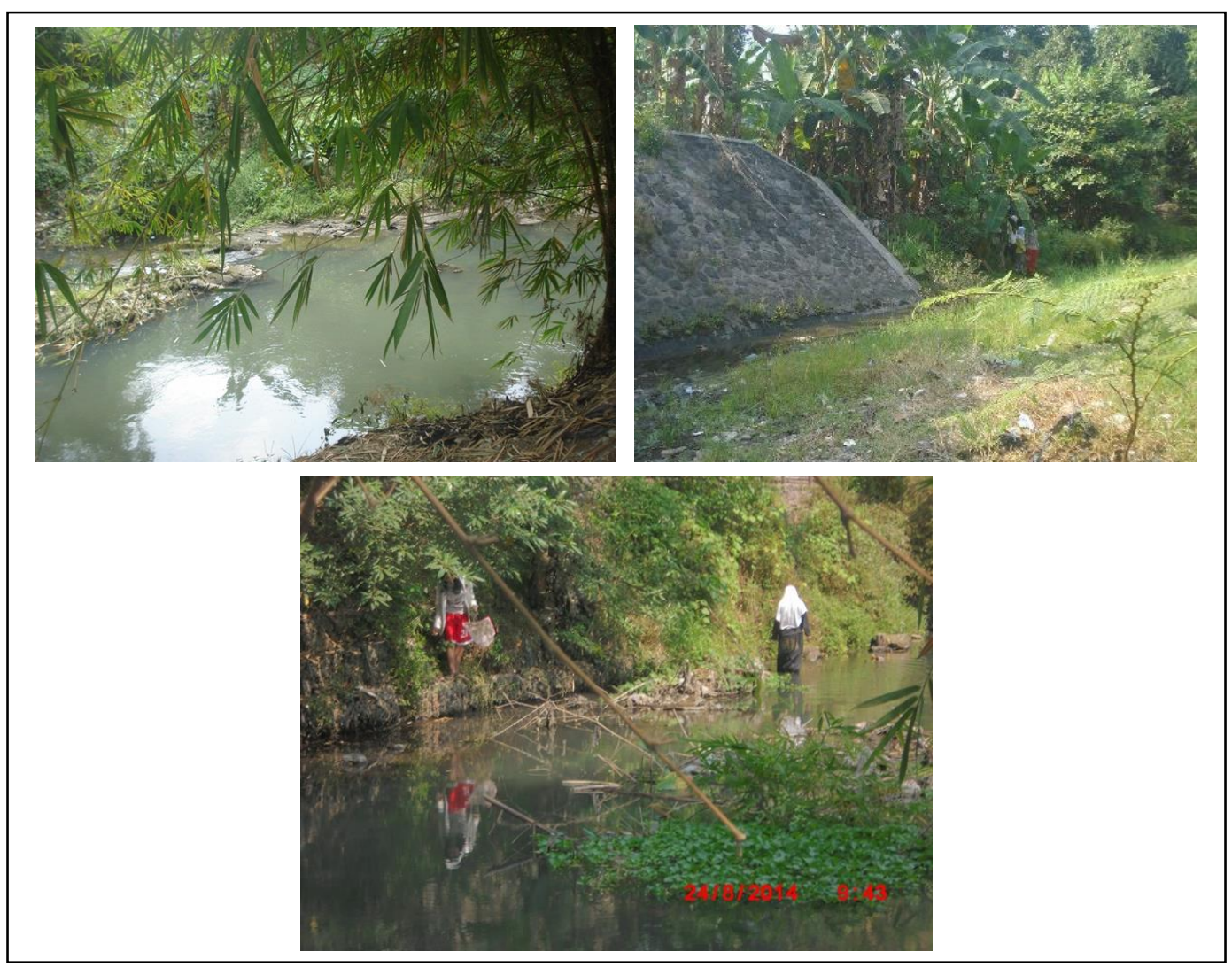

Gambar 5. Bagian Hilir Sungai Gadjah Wong, Kiri: Titik Sampling 1, tampak vegetasi riparian lebat ditepian; Kanan: Titik Sampling 2 tampak vegetasi riparian dan separuh talud; Bawah: Titik Sampling 3 tampak tepian sungai yang sempit meninggi, jauh dari hunian warga.

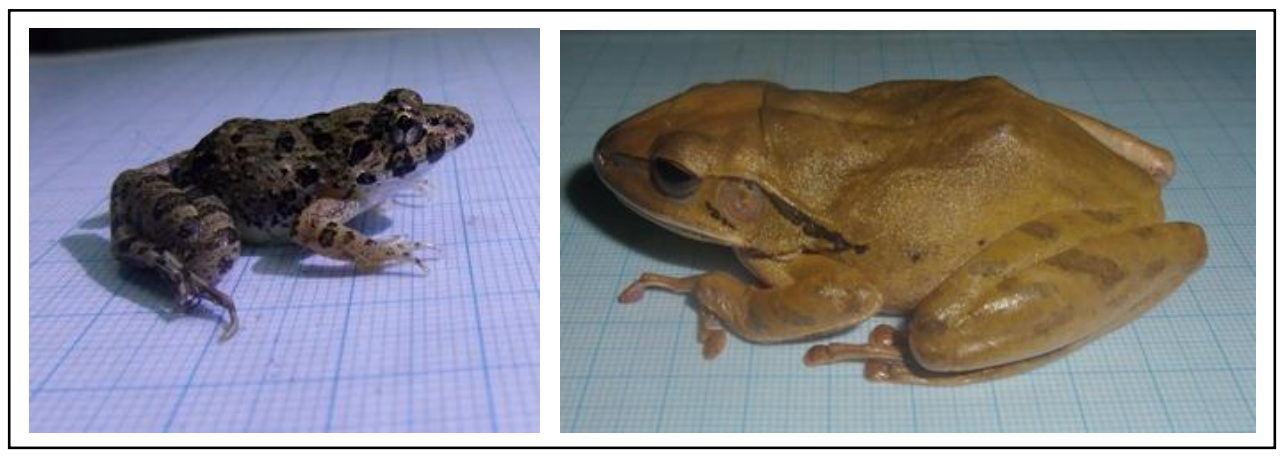

Gambar 6. Katak yang dijumpai di Hilir Sungai Gadjah Wong, kiri: Fejervarya limnocharis (Katak tegalan), dan kanan: Polypedates leucomystax (Katak pohon bergaris). 


\section{Simpulan dan Saran}

\section{Simpulan}

Katak dan kodok (Amphibia: Anura) di sepanjang sungai Gadjah Wong terdapat enam jenis dan semuanya merupakan jenis asli (native species) Indonesia. Semua katak dan kodok tersebut adalah jenis yang umum dijumpai di sekitar kita. Berdasarkan jenis yang ditemukan tersebut dapat diketahui habitatnya yaitu: 3 jenis katak akuatik dan semi-akuatik, yaitu: Chalcorana chalconota, Fejervarya limnocharis dan Occidozyga sumatrana; dan 1 jenis katak arboreal, yaitu Polypedates leucomystax; serta 2 jenis katak terrestrial, yaitu Duttaphrynus melanostictus, dan Ingerophrynus biporcatus. Sungai Gadjah Wong merupakan habitat yang cukup sesuai bagi sebagian jenis katak dan kodok.

\section{Saran}

$\begin{array}{llr} & \text { Perlu dilakukan sampling pada musim } \\ \text { hujan guna membandingkan data }\end{array}$ keanekaragaman dengan data penelitian ini. Penambahan titik sampling dan waktu penelitian yang lebih panjang.

\section{Ucapan Terima Kasih}

Terima kasih kepada Fakultas Biologi UGM yang telah memberikan dana penelitian melalui Dana Masyarakat Fakultas, Drs. Trijoko, M.Si., selaku Kepala Laboratorium Sistematika Hewan yang telah memberikan ijin kerja di Laboratorium serta adik-adik anggota Kelompok Studi Herpetologi dalam pengambilan data di lapangan dan kerja laboratorium lainnya.

\section{Daftar Pustaka}

Crump, Martha, L. dan Norman, J. Scott Jr. 1994. Visual Encounter Surveys in Measuring dan Monitoring Biological Diversity Standard Methods for Amphibians. Smithsonian Institution Press. Washington. Pp. 84.

Guyer, C. dan Donnelly, M.A. 2012. Visual Encounter Surveys In: Chapter Thirteen: Standard Techniques for Inventory and Monitoring, Reptile Biodiversity; Standard Methods for Inventory and Monitoring. University
California Press. Barkeley and Los Angeles, California. Pp. 218 - 220.

Iskandar, D.T. 1998. Amfibi Jawa dan Bali: Seri Panduan Lapangan. Cetakan pertama, Puslitbang Biologi-LIPI, Bogor. Hal : 1 - 7 .

Jaeger dan Robert, G. 1994. Transect Sampling in Measuring dan Monitoring Biological Diversity Standard Methods for Amphibians. Smithsonian Institution Press. Washington. Pp. 103.

Kurniati dan Helen. 2003. Amphibians and Reptiles of Gunung Halimun National Park, West Java, Indonesia. Research Center for Biology - LIPI and Nagao Natural Environment Foundation $\mathrm{NEF}$.

Kusrini, M.D. 2009. Pedoman Penelitian dan Survei Amfibi di Alam. Fakultas Kehutanan IPB. Bogor, Indonesia.

Pough, F.H., Andrew, R.M., Cadle, J.E., Crump, M.L., Savitzky, A.H. dan Wells, K.D. 1998. Herpetology. Prentice-Hall, Inc. Upper Saddle River, New Jersey. Pp : 138, 169.

Reynolds, R.P. dan McDiarmid, R.W. 2012. Voucher Specimens In: Chapter Six: Voucher Specimen, Reptile Biodiversity; Standard Methods for Inventory and Monitoring. University California Press. Barkeley and Los Angeles, California. Pp. 89 - 94.

Reynolds, Robert, P., Ronald, I., Crombie dan Roy, W. McDiarmid. 1994. Voucher specimens in Measuring dan Monitoring Biological DiversityStandard Methods for Amfibians. Smithsonian Institution Press. Washington. Pp. 66.

Siradz, S.A., Harsono, E.S. dan Purba, I. 2008. Kualitas Air Code, Winongo dan Gajahwong, Daerah Istimewa Yogyakarta. Jurnal Ilmu Tanah dan Lingkungan, 8 (2): 121 - 125.

Vitt, L.J. dan Caldwell, J.P. 2014. Herpetology: An Introductory Biology of Amphibians and Reptiles $4^{\text {th }} \mathrm{ed}$. Academic Press is an imprint of Elsevier. Elsevier Inc.

Yudha, D.S., Eprilurahman, R., Andryani, K. dan Trijoko. 2013. Keanekaragaman Jenis Katak dan Kodok di Sungai Code Propinsi Daerah Istimewa Yogyakarta. Jurnal Berkala Ilmiah Biologi, 12 (1) Juni: 17-25.

Yudha, D.S., Eprilurahman, R., Alawi M.F. dan Tarekat, A.A. 2014. Keanekaragaman Jenis Katak dan Kodok (ordo Anura) di Sepanjang Sungai Opak Propinsi Daerah Istimewa Yogyakarta. Jurnal Biologi, 18 (2) Desember: 52-59.

Zug, G.R., Vitt, L.J. dan Caldwell, J.P. 2001. Herpetology: An Introductory Biology of Amphibians and Reptiles $2^{\text {nd }}$ ed. Academic Press, Inc. San Diego, California. 